\title{
OXIDATIVE STRESS AND APOTOSIS TO ZEBRAFISH (DANIO RERIO) EMBRYOS EXPOSED TO PERFLUOROOCTANE SULFONATE (PFOS) AND ZNO NANOPARTICLES
}

\author{
JIA DU ${ }^{1}$, JUN CAI ${ }^{1}$, SHUTAO WANG ${ }^{2}$, and HONG YOU ${ }^{3}$
}

${ }^{1}$ Zhejiang University, Hangzhou, China

College of Humanity, Center for Urban Governance Studies (Hangzhou International Urbanology Research Center)

${ }^{2}$ Harbin Institute of Technology, Harbin, China

State Key Laboratory of Urban Water Resource and Environment

${ }^{3}$ Harbin Institute of Technology at Weihai, Weihai, China

School of Marine Science and Technology

\begin{abstract}
Objectives: Perfluorooctane sulfonate (PFOS) and zinc oxide nanoparticles (ZnO-NPs) are frequently detected in the environment but few studies have assessed the joint toxicity of them. Oxidative stress and apoptosis to zebrafish (Danio rerio) embryos induced by the PFOS and ZnO-NPs were investigated in this study. Material and Methods: The embryos were exposed to the PFOS $(0,0.4,0.8$ and $1.6 \mathrm{mg} / \mathrm{l}), \mathrm{ZnO}-\mathrm{NPs}(12.5,25,50 \mathrm{mg} / \mathrm{l})$ and PFOS plus ZnO-NPs $(0.4+12.5,0.8+25$ and $1.6+50 \mathrm{mg} / \mathrm{l})$ mixture solutions until $96 \mathrm{~h}$ post-fertilization. Activities of superoxide dismutase (SOD), catalase (CAT), glutathione peroxidase (Gpx) and malondialdehyde (MDA) content were measured in zebrafish embryos after exposure lasting for $96 \mathrm{~h}$. At the same time, the genes expression related to reactive oxygen species (ROS) generation, oxidative damage and apoptosis were also measured. Results: A significant induction of the ROS accompanied by the increase in the activity of the Gpx and MDA contents were found in co-treatment groups. Furthermore, several apoptosis pathway related genes such as Bax, p53, caspase-3 and caspase-9 were significantly up-regulated in the PFOS plus ZnO-NPs exposure groups, while anti-apoptotic gene $\mathrm{Bcl}-2$ was significantly down-regulated in the PFOS plus ZnO-NPs exposure groups. In addition, some oxidative stress-related genes such as Cat, GSH peroxidase 1 (Gpxla) and superoxide dismutase 1 (Sodl) were also significantly down-regulated after the PFOS plus ZnO-NPs co-treatments. Conclusions: The results demonstrated that the PFOS plus ZnO-NPs co-exposure could cause more serious oxidative stress and apoptosis than the PFOS and ZnO-NPs exposure alone at the exposure concentrations above. The synergistic effects of the PFOS and ZnO-NPs may be the important mechanisms of their toxicity to zebrafish embryos. Int J Occup Med Environ Health 2017;30(2):213-229
\end{abstract}

Key words:

ZnO nanoparticles, Perfluorooctane sulfonate, PFOS, Zebrafish, Oxidative stress, Apoptosis

Received: April 24, 2015. Accepted: April 26, 2016.

Corresponding authors: J. Du, Zhejiang University, College of Humanity, Center for Urban Governance Studies (Hangzhou International Urbanology Research Center), 866 Yuhangtang Rd., Xihu Dist., Hangzhou 310058, China (e-mail: dujia532158064@163.com). 


\section{INTRODUCTION}

Zinc oxide $(\mathrm{ZnO})$ nanomaterials have been widely used in the rubber industry, coating, magnetic substance, ceramic industry and many other processed products [1]. The increased use of the $\mathrm{ZnO}$ nanomaterials in industrial material has inevitably increased human and environmental exposure. Zinc oxide nanoparticles (ZnO-NPs) have accumulated in the lake and ocean in Europe [2]. Zinc oxide nanoparticles have biological toxicity in the nano-sized properties [3]. Zinc oxide nanoparticles induced inflammation response in vascular endothelial cells [4]. Zinc oxide nanoparticles also induced mitochondrial toxicity and cytotoxicity in human lung epithelial cells [5]. Zinc oxide nanoparticles induced oxidative deoxyribonucleic acid (DNA) damage and apoptosis in HepG2 cell [6].

The perfluorooctane sulfonate (PFOS) has been widely used in processed products, such as textiles, carpets, paper, propellants and insecticides for many years [7-9]. Though the PFOS has been banned in many countries in recent years, this chemical substance may still be found all over the world [10]. The concentration of the PFOS is $100 \mathrm{ng} / \mathrm{l}$ in the Tennessee River [11]. The largest concentration of the PFOS was $4385 \mathrm{ng} / \mathrm{l}$ in the Ruhr River [12]. Jin et al. (2009) found out that median concentrations (largest concentration) of the PFOS in the water were 0.4 (2.4) ng/l for the downtown $(\mathrm{N}=13)$, and $4.0(14.1) \mathrm{ng} / \mathrm{l}$ - for the city $(\mathrm{N}=22)$ in China, respectively [13]. The toxicity of the PFOS has also claimed much attention in the aquatic environment. Du et al. (2009) found that the PFOS exposure to maternal induced in malformation offspring [14]. The perfluorooctane sulfonate caused DNA damage in common carp (Cyprinus carpio) [15]. In addition, the PFOS led to bioaccumulation and histological alterations in liver, thyroid and gonads of zebrafish (Danio rerio) [16].

The biology of particle-induced oxidative stress is an important mechanistic paradigm, on the basis of which a predictive model for studying engineered nanomaterials toxicity has been developed [17]. The imbalance between reactive oxygen species (ROS) and antioxidant defense induced the oxidative stress [18]. Deoxyribonucleic acid damage and cellular apoptosis induced the ROS generation [6]. The antioxidant enzymes (superoxide dismutase (SOD), catalase (CAT) and glutathione peroxidase $(\mathrm{Gpx})$ ) reduced the damage of the excessive ROS in organism [19]. Zinc oxide nanoparticles through the oxidative stress induced oxidative damage [20]. Zinc oxide nanoparticles exposure to zebrafish embryo induced the cellular oxidative stress response and the ROS generation [21]. The perfluorooctane sulfonate could induce oxidative stress and apoptosis in the lung of rat offspring [22]. Apoptosis is the process of programmed cell death (PCD) that occurs in multicellular organisms. The caspase family plays an important role in the induction, transduction and amplification of intracellular apoptotic signals [23]. The p53 protein regulates the cell cycle and apoptosis induction in multicellular organisms [24]. When p53 was activated, it induced the expression of Bax gene and activated the effector caspase-3 [25]. Bcl-2 was an apparent antioxidant to prevent apoptosis [26]. The perfluorooctane sulfonate triggered the transactivation of Bax and activate caspase-3 and caspase-9 in zebrafish embryos [27]. Zinc oxide nanoparticles were found to elicit caspase-3 activation and induce Bax gene expression in cultured primary astrocytes [28]. Ahamed et al. (2011) found that ZnO-NPs induced apoptotic cell death by oxidative stress [20]. Aquatic organisms are exposed to mixtures of chemicals for a long time. Many studies have evaluated the biological toxicity of the PFOS and ZnO-NPs by investigating exposure to individual toxicant $[16,29]$. Some studies have focused on the combination of organic contaminants or inorganic contaminants to study the joint toxicity [30]. Combined toxicity assessment should adopt co-exposure models [31]. Sarigiannis and Hansen (2012) have provided that combined toxicity assessment should consider the cumulative effects [32]. There is inadequate data used for assessing the joint effect of the PFOS and $\mathrm{ZnO}-\mathrm{NPs}$ exposure on oxidative stress and 
apoptosis. In addition, the molecular mechanism of their joint toxicity remains largely unclear.

In this research, zebrafish was used for evaluating the joint effects of the PFOS and ZnO-NPs on oxidative stress and apoptosis pathways. Indicators such as the SOD activity, malondialdehyde (MDA) content, CAT activity, Gpx activity, caspase- 9 activity, caspase-3 activity and the level of ROS were examined. Gene expression patterns related to the apoptosis pathway (pro-apoptotic p53, and Bax), apoptosis protease-activating factor (caspase-9 and caspase-3), anti-apoptotic ( $\mathrm{Bcl}-2)$ and oxidative stress (Cat, Gpx1a and Sod1) were also examined to elucidate the potential molecular mechanism underlying the induction of oxidative stress and apoptosis by the PFOS and ZnO-NPs.

\section{MATERIAL AND METHODS}

\section{Chemicals and preparation of stock solutions}

Heptadecafluorooctanesulfonic acid (PFOS) potassium salt (Chemical Abstracts Service (CAS) No. 2795-39-3; $\geq 98 \%$ purity), heptadecafluorooctanesulfonic acid potassium salt (PFOS; CAS No. 2795-39-3; analytical standard (Fluka), dimethyl sulfoxide (DMSO, $\geq 99.9 \%$ ), ZnO-NPs (CAS No. 1314-13-2, St. Louis, MO, USA). Other chemicals and solvents were of analytical grade.

\section{Characterization of $\mathrm{ZnO}$-NPs}

Zinc oxide nanoparticles solutions were dispersed by the Ultrasonic processor for $20 \mathrm{~min}$. A series of the $\mathrm{ZnO}$ NPs solutions were prepared by means of stepwise dilution with zebrafish culture medium. The morphology of the ZnO-NPs aggregates were observed using a scanning electron microscope (Photo 1a) and a transmission electron microscopy (TEM) system (Photo $1 \mathrm{~b}$ ). The images revealed that the average size of $\mathrm{ZnO}-\mathrm{NPs}$ was $40 \mathrm{~nm}$. The particle size distribution of the $\mathrm{ZnO}$-NPs was obtained by a dynamic light scattering (DLS) device, and the results showed polydispersed aggregates characterized by single particles of $30-100 \mathrm{~nm}$ in size (Photo $1 \mathrm{~b}$ ).
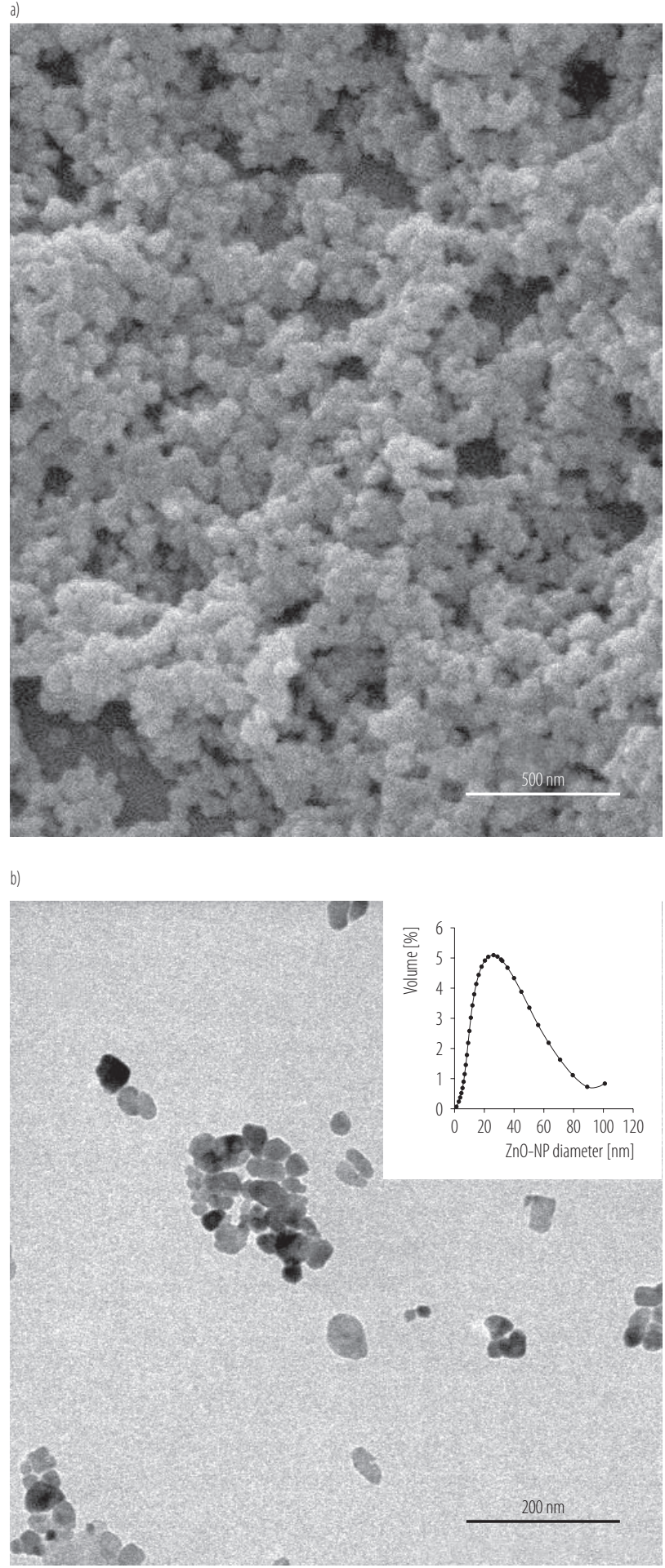

Photo 1. a) Zinc oxide nanoparticles (ZnO-NPs) suspension of $50 \mathrm{mg} / \mathrm{l}$ (scanning electron microscopy), b) ZnO-NPs suspension of $50 \mathrm{mg} / \mathrm{l}$ (transmission electron microscopy) and particle size distribution (dynamic light scattering - DLS) 


\section{Chemical analysis}

Zinc oxide nanoparticles solutions were centrifuged at $10000 \mathrm{~g}$ for $30 \mathrm{~min}$, and dissolved zinc $\left(\mathrm{Zn}^{2+}\right)$ was measured by the inductively coupled plasma-mass spectrometer (ICP-MS) (Thermo Elemental X7, Thermo Electron Co., USA). The perfluorooctane sulfonate concentrations were analyzed by means of the solid phase extraction (SPE) and liquid chromatography-tandem mass spectrometry (LC-MS/MS) [12].

\section{Zebrafish maintenance}

Adult $\mathrm{AB}$ strain zebrafishes were fed twice daily with frozen blood worms, and kept at approximate $28^{\circ} \mathrm{C}$ under $14 \mathrm{~h}$ light: $10 \mathrm{~h}$ dark in the beaker. Zebrafishes were paired in spawning boxes overnight. Spawning was accomplished at 7 a.m., and then the fertilized eggs were collected and transferred to culture water to rinse.

\section{Samples exposure}

The normal embryos were exposed to the $\mathrm{ZnO}-\mathrm{NPs}$ solution $(1,5,10,20,50,100,200 \mathrm{mg} / \mathrm{l})$ and PFOS solution $(1,2,4,8,16 \mathrm{mg} / \mathrm{l})$. It was concluded that the $96 \mathrm{~h}$ lethal concentration $\left(\mathrm{LC}_{50}\right)$ of $\mathrm{ZnO}-\mathrm{NPs}$ and PFOS were $60 \mathrm{mg} / \mathrm{l}$ and $3.502 \mathrm{mg} / 1$, respectively (Table 1). The mortality of zebrafish was the same after having been exposed to the PFOS (1.6 mg/l) and ZnO-NPs (50 mg/l) (Table 2). The results showed that the PFOS $(1.6 \mathrm{mg} / \mathrm{l})$ and $\mathrm{ZnO}-\mathrm{NPs}$ (50 mg/l) exposure caused the obvious symptom as compared with the control. The exposure concentrations of the $\mathrm{ZnO}-\mathrm{NPs}$ were $0,12.5,25,50 \mathrm{mg} / \mathrm{l}$ and PFOS were $0,0.4$, $0.8,1.6 \mathrm{mg} / \mathrm{l}$, respectively. The exposure concentrations of the PFOS were higher than those measured in the water of China in this research [13]. However, it was an appropriate method to use the relatively higher concentration of toxicants to elicit the possible toxicity mechanisms in the laboratory short-term exposures [29,33,34]. Four hundred normal embryos were put into every beaker containing $500 \mathrm{ml}$ of the $\mathrm{ZnO}-\mathrm{NPs}$ plus PFOS $(12.5+0.4,25+0.8,50+1.6 \mathrm{mg} / \mathrm{l})$,
Table 1. The 96-h lethal concentration $\left(\mathrm{LC}_{50}\right)$ of zinc oxide nanoparticles (ZnO-NPs) and perfluorooctane sulfonate (PFOS) to zebrafish embryo

\begin{tabular}{lcc}
\hline \multirow{2}{*}{ Particle } & \multicolumn{2}{c}{$96-\mathrm{h} \mathrm{LC}_{50}$} \\
\cline { 2 - 3 } & $\mathrm{mg} / \mathrm{l}$ & $95 \% \mathrm{CI}$ \\
\hline ZnO-NPs & 60.000 & $83.35-44.16$ \\
PFOS & 3.502 & $2.369-5.051$ \\
\hline
\end{tabular}

CI - confidence interval.

Table 2. The 96-h mortality of zebrafish embryo after exposure to zinc oxide nanoparticles ( $\mathrm{ZnO}-\mathrm{NPs}$ ) and perfluorooctane sulfonate (PFOS)

\begin{tabular}{|c|c|c|}
\hline \multicolumn{2}{|c|}{ Study group exposure } & \multirow{2}{*}{$\begin{array}{c}\text { Zebrafish embryo } \\
\text { 96-h mortality } \\
(\mathrm{M} \pm \mathrm{SD})\end{array}$} \\
\hline particle & $\begin{array}{c}\text { concentration } \\
{[\mathrm{mg} / \mathrm{l}]}\end{array}$ & \\
\hline \multirow[t]{6}{*}{$\mathrm{ZnO}-\mathrm{NPs}$} & 1.0 & $15.00 \pm 2.10$ \\
\hline & 5.0 & $22.25 \pm 4.67$ \\
\hline & 10.0 & $27.67 \pm 3.58$ \\
\hline & 20.0 & $23.00 \pm 7.89$ \\
\hline & 50.0 & $25.33 \pm 4.43$ \\
\hline & 100.0 & $31.00 \pm 3.41$ \\
\hline \multirow[t]{6}{*}{ PFOS } & 0.3 & $10.00 \pm 4.80$ \\
\hline & 0.5 & $14.36 \pm 6.34$ \\
\hline & 0.8 & $11.71 \pm 2.60$ \\
\hline & 1.2 & $15.00 \pm 3.95$ \\
\hline & 1.6 & $25.10 \pm 5.32$ \\
\hline & 2.0 & $30.00 \pm 2.34$ \\
\hline Control & 0.0 & $9.66 \pm 0.25$ \\
\hline
\end{tabular}

M - mean; SD - standard deviation.

PFOS single (0, 0.4, 0.8, $1.6 \mathrm{mg} / \mathrm{l})$ and $\mathrm{ZnO}$-NPs single ( 0 , $12.5,25$ and 50), respectively. Reactive oxygen species measurement was performed after $96 \mathrm{~h}$ exposure to larvae. The tested samples were stored at $-80^{\circ} \mathrm{C}$.

\section{Antioxidant enzymes activity analysis}

Three replicates of samples were homogenized in buffer solution (0.01 M Tris hydrochloride (Tris-HCl), $0.0001 \mathrm{M}$ ethylenediaminetetraacetic acid 2Na (EDTA-2Na), 0.01 M 
Table 3. Primer sequences for the genes tested in this study of oxidative stress and apoptosis to zebrafish (Danio rerio) embryos exposed to perfluorooctane sulfonate and ZNO nanoparticles

\begin{tabular}{llll}
\hline \multirow{2}{*}{ Gene } & \multicolumn{2}{c}{ forward } & \multicolumn{1}{c}{$\begin{array}{c}\text { Gene bank } \\
\text { accession number }\end{array}$} \\
\cline { 2 - 3 } \cline { 2 - 3 } s-actin & CGGGTGGAGTTTGACACTT & CTCCCTGATGCTGGGTCGTC & AF057040 \\
SoD1 & GGCCAACCGATAGTGTTAGA & CCAGCGTTGCCAGTTTTAG & Y12236.1 \\
GPx1a & AGGGCAACTGGGATCTTACA & TTTATGGGACCAGACCTTGG & NM130912.1 \\
Bax & ACCTGTCCGCGAAACTATTG & TGACTGTTGTGCCTCAAAGC & NM00100728 \\
p53 & GGCTATTTCAACCAGGGTCC & TGCGAATCACCAATGCTGT & AF231015 \\
Bcl-2 & GGGCAATCAGCGAGCAAA & ACTGACCTTCCTGAGTCTCCA & AF365873 \\
Caspase-3 & TCACTCGTTCAGACCCTCAT & ACGCTTTCCACGCACAT & NM001030253 \\
Caspase-9 & CCGCTGCCCATCACTA & ATCCTTTCACGACCATCT & NM131877 \\
\hline
\end{tabular}

sucrose, $0.8 \%$ sodium chloride $(\mathrm{NaCl}))$. The tissue homogenates were centrifuged at $2000 \mathrm{r} / \mathrm{min}$ for $15 \mathrm{~min}$ at $4^{\circ} \mathrm{C}$. Superoxide dismutase activity was determined by measuring the inhibition of the auto-oxidation of epinephrine at $\mathrm{pH} 10.2$ and $25^{\circ} \mathrm{C}$ [35]. The catalase activity was measured by means of the absorbance of hydrogen peroxide at $240 \mathrm{~nm}$ [36]. Lipid peroxidation products were measured using the method of thiobarbituric acid (TBA) [37]. Malondialdehyde was an end-lipid peroxidation product which performed a pink product after having reacted with the TBA reagent. The glutathione peroxidase activity was measured by using the method of Paglia and Valentine [38]. Total protein content in the samples was assayed by means of the Bradford method [39].

\section{ROS analysis}

Reactive oxygen species generated in samples after having been exposed to the PFOS and $\mathrm{ZnO}$-NPs for $96 \mathrm{~h}$ were determined by means of the dichlorofluorescein-diacetate (DCFH-DA). Ten larvae were rinsed and homogenized in buffer solution. The samples were centrifuged and the supernatant was collected. One hundred and fifty microliters of the supernatant and $10 \mu \mathrm{l}$ DCFH-DA stock solutions were put into 96 -well plate and incubated at $25^{\circ} \mathrm{C}$ for $300 \mathrm{~s}$.
The 96-well plate was kept at $37^{\circ} \mathrm{C}$ dark incubator for $30 \mathrm{~min}$. The fluorescence intensity was determined by means of the micro plate reader with excitation and emission at $485 \mathrm{~nm}$ and $530 \mathrm{~nm}$. The total protein was determined using protein assay kits (Jiancheng Biochemistry Co., Nanjing, China). The concentrations of the ROS were determined in arbitrary units (dichlorofluorescein milligram per protein).

\section{Caspase activity assay}

The caspase activity was determined by means of the colorimetric assay according to the extent to acetyl-AspGlu-Val-Asp-nitroanilide and acetyl-Leu-Glu-His-Asp pnitroanilide, respectively. The chemicals converted into yellow formazan products. In a typical procedure, after $96 \mathrm{~h}$, 80 hatched larvae were rinsed with cold buffer solution and homogenised for $300 \mathrm{~s}$. The solution was then centrifuged at $12000 \mathrm{~g}$ for $15 \mathrm{~min}$ at $4^{\circ} \mathrm{C}$, and the supernatant was collected. The caspase activities were expressed in terms of the percentage enzyme activity compared with the control.

\section{Quantitative real-time PCR assay}

Ribonucleic acid was extracted using Trizol Reagent after having been exposed for $96 \mathrm{~h}$. Then the RNA was digested 
and purified by using RNase-free DNase I. Pure RNA was measured at 260 and $280 \mathrm{~nm}$ using a spectrophotometer. Quantitative reverse transcription polymerase chain reaction (RT-PCR) was performed with $\mathrm{ABI} 7500$ by SYBR Green PCR kit (TaKaRa). The primer sequences of $\beta$-actin, Sod1, Cat, Gpx1a, Bcl-2, Bax, P53, caspase-3 and caspase- 9 are shown in the Table 1 . The thermal cycle was as follows: initial denaturation for $10 \mathrm{~min}$ at $95^{\circ} \mathrm{C}$ followed by 39 cycles of $95^{\circ} \mathrm{C}$ for $30 \mathrm{~s}, 60^{\circ} \mathrm{C}$ for $20 \mathrm{~s}$ and $72^{\circ} \mathrm{C}$ for $1 \mathrm{~min}$. Reverse transcription polymerase chain reaction was carried out for 3 replicate samples. The expression level was normalized to $\beta$-actin messenger ribonucleic acid (mRNA) content. The level of gene was measured by the $2^{-\Delta \Delta C t}$ method [40].

\section{Statistical analysis}

Data was presented with standard errors (mean (M) \pm standard error of the mean (SEM)) and the statistical analysis was carried out with one-way analysis of variance (ANOVA) followed by least significant difference (LSD) and Dunnett's T3 test. Significant differences between the PFOS and $\mathrm{ZnO}$-NPs were compared by the independent-sample t test using SPSS 18.0 software (SPSS, USA). A p-value $<0.05$ was deemed statistically significant in all experiments.

\section{RESULTS}

\section{Chemical analysis}

Zinc $^{2+}$ released from exposure suspensions (12.5, 25 and $50 \mathrm{mg} / \mathrm{l}$ ) was $9.85,9.22$ and $22.58 \mathrm{mg} / \mathrm{l}$ based on the results of the ICP-MS, respectively. In addition, the series of the PFOS and $\mathrm{ZnO}-\mathrm{NPs}$ exposure suspensions $(0.4+12.5$, $0.8+25$ and $1.6+50 \mathrm{mg} / \mathrm{l}$ ) were $5.25,13.15$ and $30.38 \mathrm{mg} / \mathrm{l}$, respectively. From the analysis results of the LC-MS/MS, the linear equation was obtained: $\mathrm{Y}=88133.5+14149.75 \mathrm{X}$ $\left(\mathrm{R}^{2}=0.996\right)$ and $\mathrm{Y}$ secondary sub ion $(\mathrm{m} / \mathrm{z} 499.2>79.9)$. The results showed that the PFOS linear relation was good in the concentration of 0.05 to $1.8 \mathrm{mg} / \mathrm{l}$. The concentrations of the PFOS from the series of exposure suspensions $(0.4,0.8$ and $1.6 \mathrm{mg} / \mathrm{l})$ were $0.33,0.64$ and $1.23 \mathrm{mg} / \mathrm{l}$, respectively. The series of the PFOS and $\mathrm{ZnO}-\mathrm{NPs}$ exposure suspensions $(0.4+12.5,0.8+25$ and $1.6+50 \mathrm{mg} / \mathrm{l})$ were $0.31,0.54$ and $1.19 \mathrm{mg} / \mathrm{l}$, respectively. After having been verified analytically, the exposure concentrations used in this study in terms of the results proved that renewed solutions daily was appropriate for the PFOS and $\mathrm{ZnO}-\mathrm{NPs}$ to ensure that exposures concentrations were at the intended level.

\section{Activity of antioxidant enzymes}

The superoxide dismutase activity was significantly increased in a dose-dependent manner in all groups (except for 0.4 and $0.8 \mathrm{mg} / 1$ PFOS single-treatment) compared with that in the control $(\mathrm{p}<0.05)$ (Figure 1a). The superoxide dismutase activity was significantly increased in 0.4 , 0.8 and $1.6 \mathrm{mg} / \mathrm{l}$ of the PFOS joint exposure groups relative to $0.4,0.8$ and $1.6 \mathrm{mg} / \mathrm{l}$ PFOS single exposure groups, respectively.

The catalase activity was significantly decreased in $1.6 \mathrm{mg} / \mathrm{l}$ of the PFOS joint exposure groups compared to $1.6 \mathrm{mg} / \mathrm{l}$ of the PFOS single exposure group ( $p<0.05$ ) (Figure $1 b$ ). The catalase activity was significantly decreased in a dosedependent manner in all the ZnO-NPs single-treatment, $12.5 \mathrm{mg} / \mathrm{l}$ of the $\mathrm{ZnO}-\mathrm{NPs}$ co-treatment and $50 \mathrm{mg} / \mathrm{l}$ of the $\mathrm{ZnO}$-NPs joint exposure groups compared to the control $(\mathrm{p}<0.05)$. In addition, the CAT activities were not significantly decreased in the PFOS single-treatment groups as compared to the control.

Glutathione peroxidase activities in zebrafish embryo were found to be increased significantly in all groups (except for 0.4 and $0.8 \mathrm{mg} / \mathrm{l}$ PFOS single exposure groups) as compared to the control (Figure 1c). Significant increases were similarly observed in $0.4,0.8$ and $1.6 \mathrm{mg} / \mathrm{l}$ of the PFOS joint exposure groups compared to $0.4,0.8$ and $1.6 \mathrm{mg} / \mathrm{l}$ of the PFOS single exposure group $(\mathrm{p}<0.05)$. Glutathione peroxidase activities were also significantly 

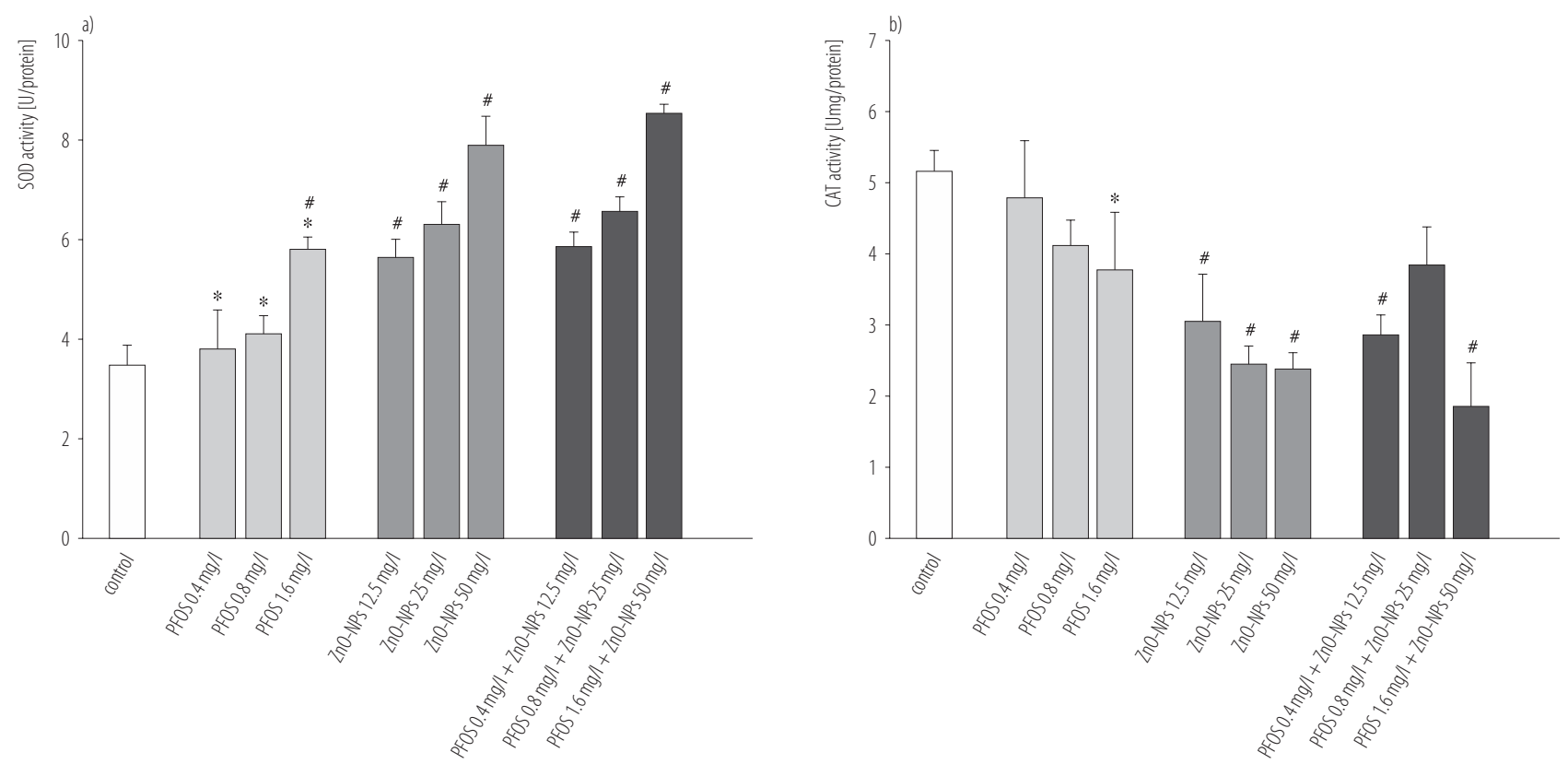

Study group exposure

Study group exposure
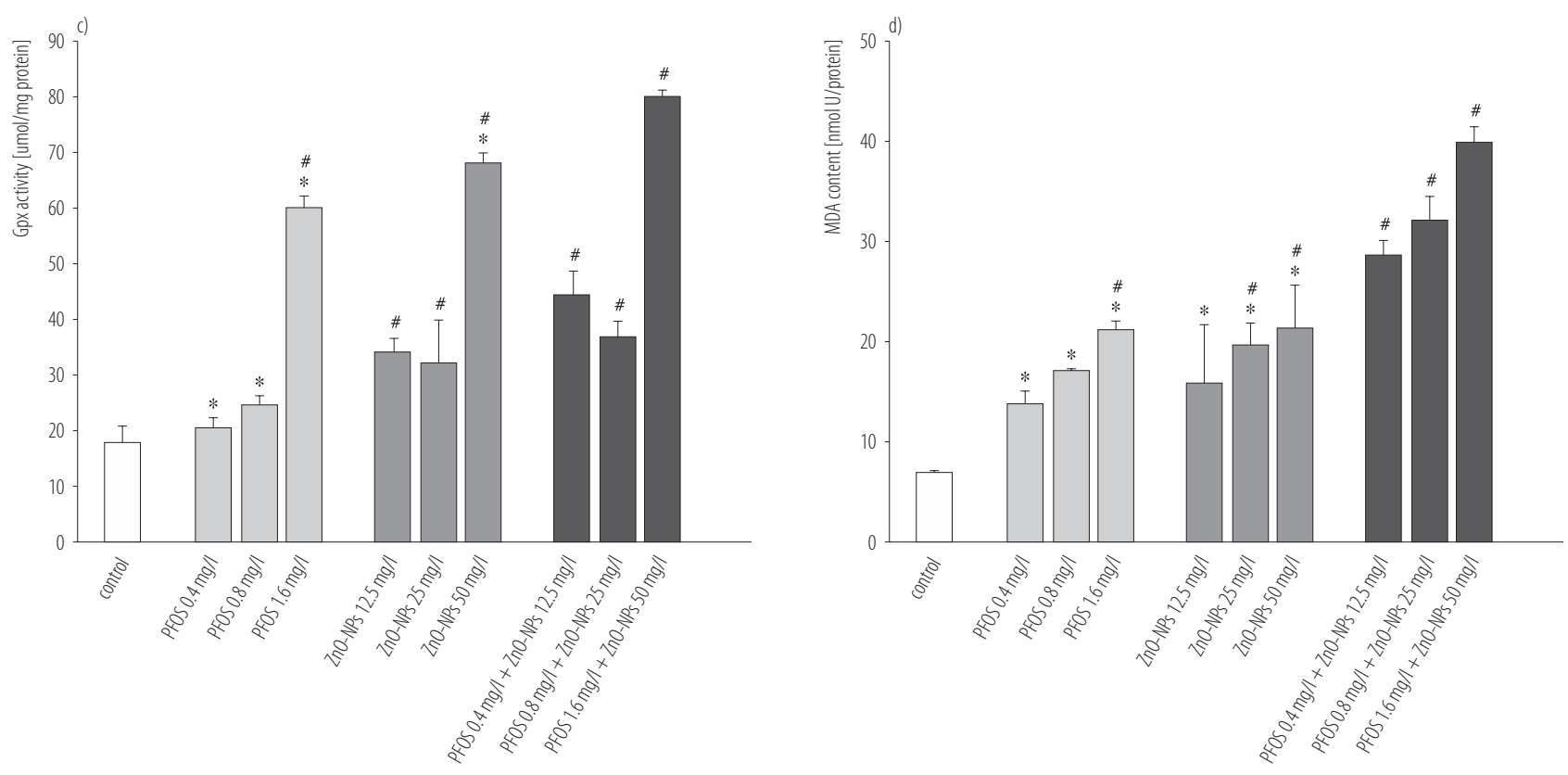

Study group exposure

Study group exposure

* Statistically significant difference from PFOS and ZnO-NPs co-exposure at $\mathrm{p}<0.05$ level.

\# Statistically significant difference from control at $\mathrm{p}<0.05$ level.

Values represent the mean \pm standard error of 3 replicates $(p<0.05)$.

Fig. 1. a) Superoxide dismutase (SOD), b) catalase (CAT), and c) glutathione peroxidase (GPx) activity and d) malondialdehyde (MDA) content in zebrafish embryos after exposure to perfluorooctane sulfonate (PFOS) and zinc oxide nanoparticles (ZnO-NPs) at $96 \mathrm{~h}$ post-fertilisation 


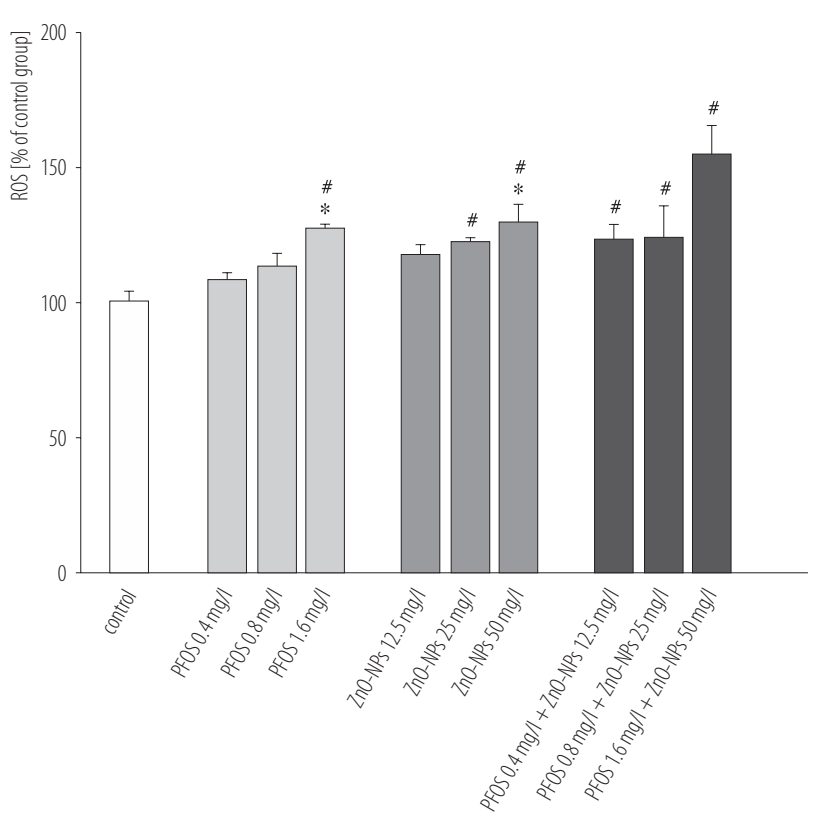

Study group exposure

Explanations as in Figure 1.

Fig. 2. Reactive oxygen species (ROS) level in zebrafish embryos after exposure to perfluorooctane sulfonate (PFOS) and zinc oxide nanoparticles (ZnO-NPs) at $96 \mathrm{~h}$ post-fertilization

increased in 12.5 and $50 \mathrm{mg} / \mathrm{l}$ of the ZnO-NPs joint exposure groups compared to 12.5 and $50 \mathrm{mg} / \mathrm{l}$ of the $\mathrm{ZnO}-\mathrm{NPs}$ single-treatment groups.

Malondialdehyde content was significantly increased in $1.6 \mathrm{mg} / \mathrm{l}$ PFOS single exposure and all the PFOS joint exposure groups compared to the control $(\mathrm{p}<0.05)$ (Figure 1d). Moreover, significant increases were also observed in 0.8 and $1.6 \mathrm{mg} / \mathrm{l}$ of the PFOS joint exposure compared with that in 0.8 and $1.6 \mathrm{mg} / \mathrm{l}$ of the PFOS single exposure groups. In addition, there were also significant increases in 25 and $50 \mathrm{mg} / \mathrm{l}$ of the $\mathrm{ZnO}-\mathrm{NPs}$ joint exposure compared with that in 25 and $50 \mathrm{mg} / \mathrm{l}$ of the $\mathrm{ZnO}-\mathrm{NPs}$ single-treatment groups.

It was found that after exposure to $1.6 \mathrm{mg} / \mathrm{l}$ of the PFOS single-treatment, $50 \mathrm{mg} / \mathrm{l}$ of the $\mathrm{ZnO}$-NPs single-treatment and $1.6 \mathrm{mg} / \mathrm{l}$ of the PFOS and $50 \mathrm{mg} / \mathrm{l}$ of the $\mathrm{ZnO}$-NPs joint exposure groups, the levels of the ROS were significantly increased as compared with that in the control $(\mathrm{p}<0.05)$ (Figure 2). The levels of the ROS in 0.8 and $1.6 \mathrm{mg} / \mathrm{l}$ of the PFOS joint exposure groups were significantly increased as compared with that in 0.8 and $1.6 \mathrm{mg} / \mathrm{l}$ of the PFOS single exposure groups $(\mathrm{p}<0.05)$. Moreover, the level of the ROS in $1.6 \mathrm{mg} / \mathrm{l}$ of the $\mathrm{ZnO}$-NPs co-treatment group was significantly increased to $50 \mathrm{mg} / \mathrm{l}$ of the ZnO-NPs single-treatment group.

\section{Effects of $\mathrm{ZnO}$-NPs on the expression}

\section{of gene related to the antioxidant defence system}

The mRNA expression levels of the PFOS and ZnO-NPs exposure were measured by RT-PCR (Figure 3). The expression level of the Cat gene was significantly downregulated in $1.6 \mathrm{mg} / \mathrm{l}$ of the PFOS single exposure group, 0.8 and $1.6 \mathrm{mg} / \mathrm{l}$ of the PFOS joint exposure groups ( 0.81 , 0.77 and 0.75 -fold; $p<0.05$ ) (Figure $3 \mathrm{a}$ ). The transcription of the Cat gene in $0.8 \mathrm{mg} / \mathrm{l}$ of the PFOS and $25 \mathrm{mg} / \mathrm{l}$ of the ZnO-NPs joint exposure group was significantly increased as compared with that in $0.8 \mathrm{mg} / \mathrm{l}$ of the PFOS and $25 \mathrm{mg} / \mathrm{l}$ of the ZnO-NPs single-treatment groups. The mRNA levels of Gpx1a in zebrafish larvae were significantly decreased by $0.72,0.72$ and 0.38 -fold after treatment with $1.6 \mathrm{mg} / \mathrm{l}$ of the PFOS single-treatment, $0.8 \mathrm{mg} / \mathrm{l}$ of the PFOS co-treatment and $1.6 \mathrm{mg} / \mathrm{l}$ of the PFOS joint exposure groups compared with that in the control (Figure 3b). In addition, the expression levels of Gpx1a in zebrafish larvae were significantly decreased in $1.6 \mathrm{mg} / \mathrm{l}$ of the PFOS and $50 \mathrm{mg} / \mathrm{l}$ of the ZnO-NPs cotreatment groups compared to $1.6 \mathrm{mg} / \mathrm{l}$ of the PFOS single-treatment and $50 \mathrm{mg} / \mathrm{l}$ of the $\mathrm{ZnO}-\mathrm{NPs}$ singletreatment groups. Sod1 mRNA expression was significantly affected by $1.6 \mathrm{mg} / \mathrm{l}$ of the PFOS single and joint exposure groups compared to the control (Figure 3c). The expression of Sod1 mRNA in $1.6 \mathrm{mg} / \mathrm{l}$ of the PFOS and $50 \mathrm{mg} / \mathrm{l}$ of the ZnO-NPs co-treatment group was significantly decreased to $1.6 \mathrm{mg} / \mathrm{l}$ of the PFOS and $50 \mathrm{mg} / \mathrm{l}$ of the $\mathrm{ZnO}-\mathrm{NPs}$ single-treatment groups. 


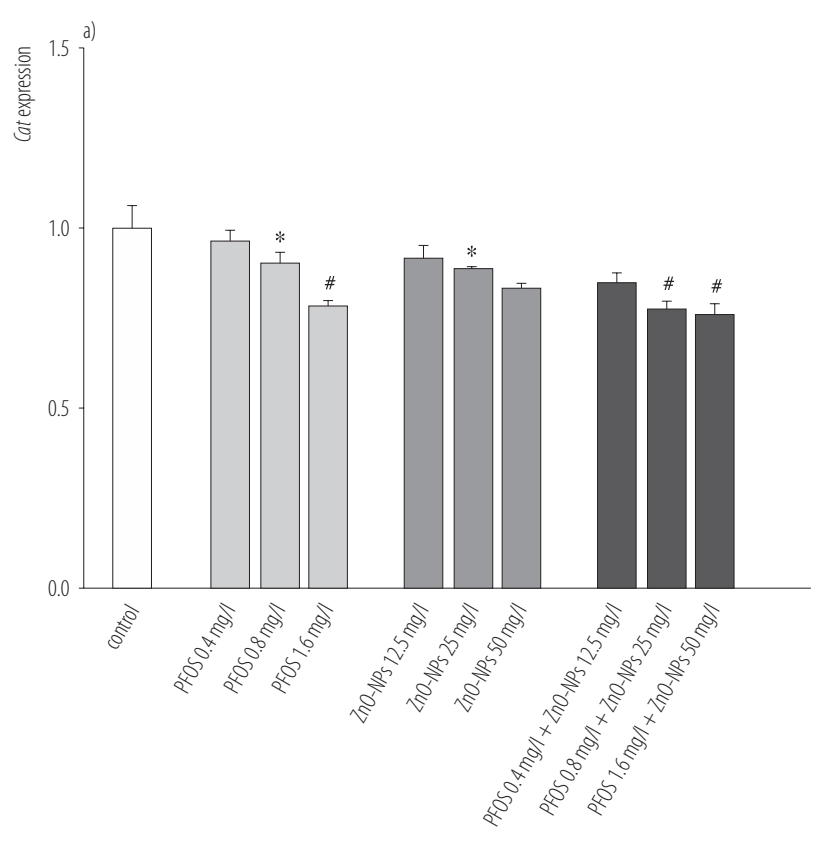

Study group exposure

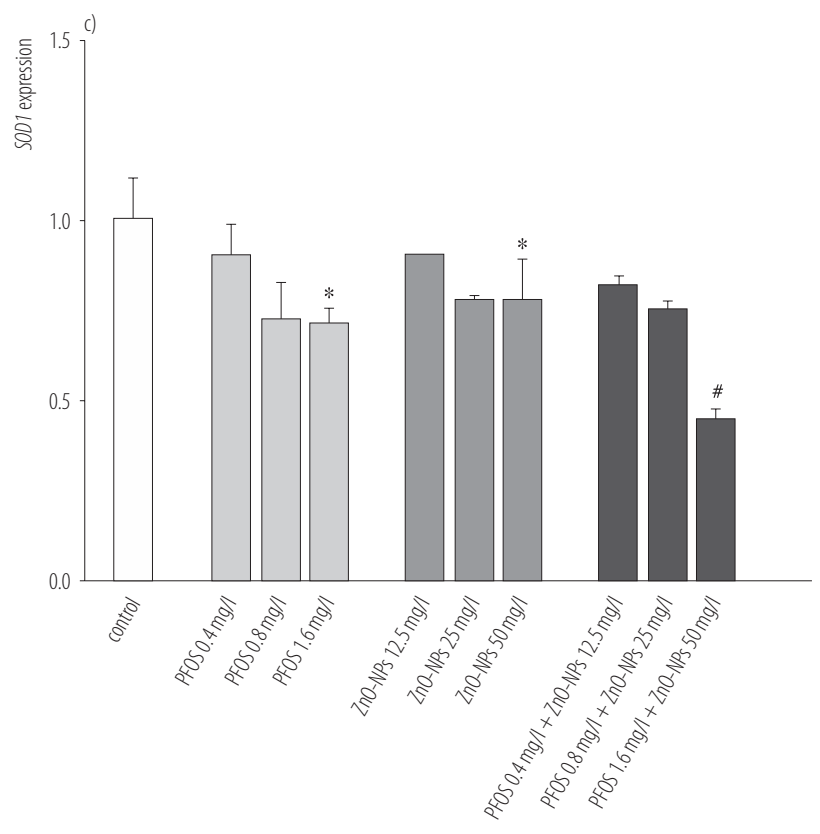

Study group exposure

\section{Effects of PFOS and ZnO-NPs}

\section{on Caspase- 3 and Caspase- 9 activities}

In order to determine whether the PFOS and $\mathrm{ZnO}-\mathrm{NPs}$ induced apoptosis through the caspase pathway, the Caspase- 3 and Caspase- 9 activities were examined. After the

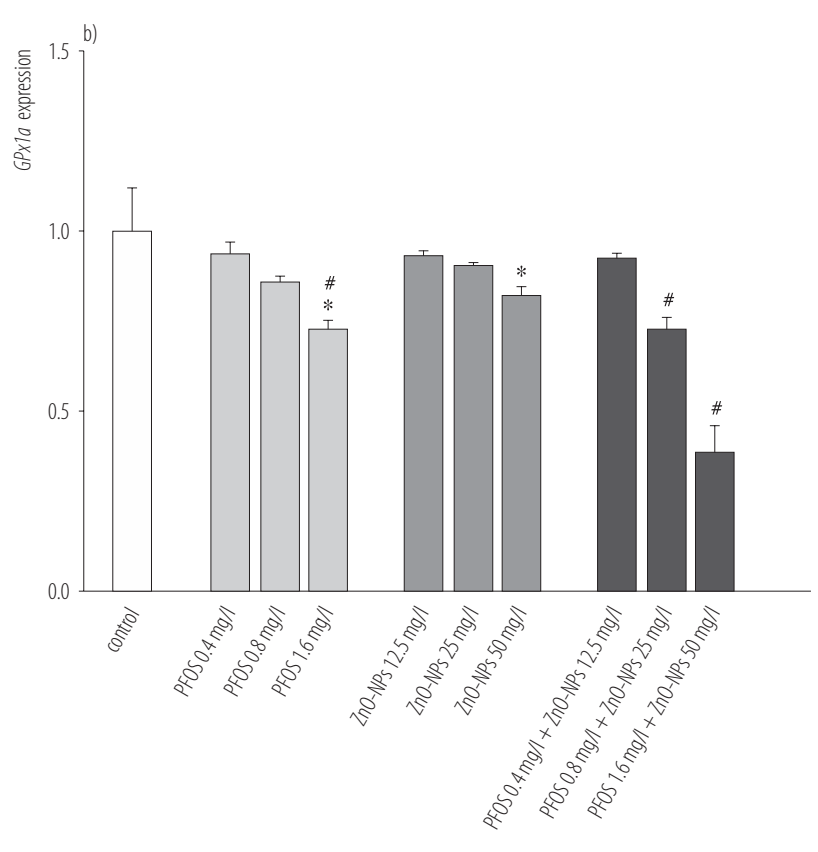

Study group exposure

Explanations as in Figure 1.

Fig. 3. a) Cat, b) GPx1a and c) SOD1 gene expression levels in zebrafish embryos after exposure to perfluorooctane sulfonate (PFOS) and zinc oxide nanoparticles (ZnO-NPs) at $96 \mathrm{~h}$ post-fertilization

PFOS and $\mathrm{ZnO}-\mathrm{NPs}$ joint exposure, the activities were significantly increased in a concentration-dependent manner (Figure 4). As shown in the Figure 4a, the Caspase 3 activities were significantly increased in $1.6 \mathrm{mg} / \mathrm{l}$ of the PFOS single-treatment, $0.8 \mathrm{mg} / \mathrm{l}$ of the PFOS and $1.6 \mathrm{mg} / \mathrm{l}$ of the PFOS joint exposure groups compared with that in the control $(\mathrm{p}<0.05)$. The level of the Caspase 3 activity in $0.8 \mathrm{mg} / \mathrm{l}$ of the PFOS joint exposure group was significantly increased to $0.8 \mathrm{mg} / \mathrm{l}$ of the PFOS single exposure group $(\mathrm{p}<0.05)$. In addition, the Caspase 3 activities in the $\mathrm{ZnO}$-NPs co-treatment groups were significantly increased as compared with that in the ZnO-NPs single-treatment groups. The Caspase 9 activities were significantly increased in $1.6 \mathrm{mg} / \mathrm{l}$ of the PFOS single exposure group, $0.8 \mathrm{mg} / \mathrm{l}$ of the PFOS co-treatment and $1.6 \mathrm{mg} / \mathrm{l}$ of the PFOS cotreatment groups as compared to the control (Figure 4b). 


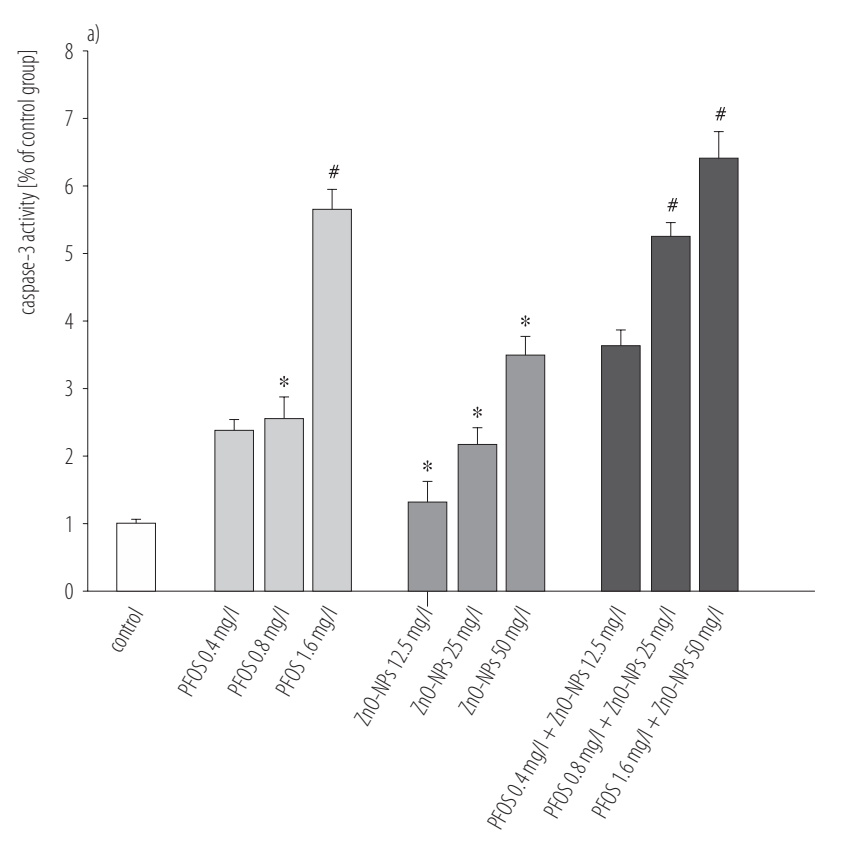

Study group exposure

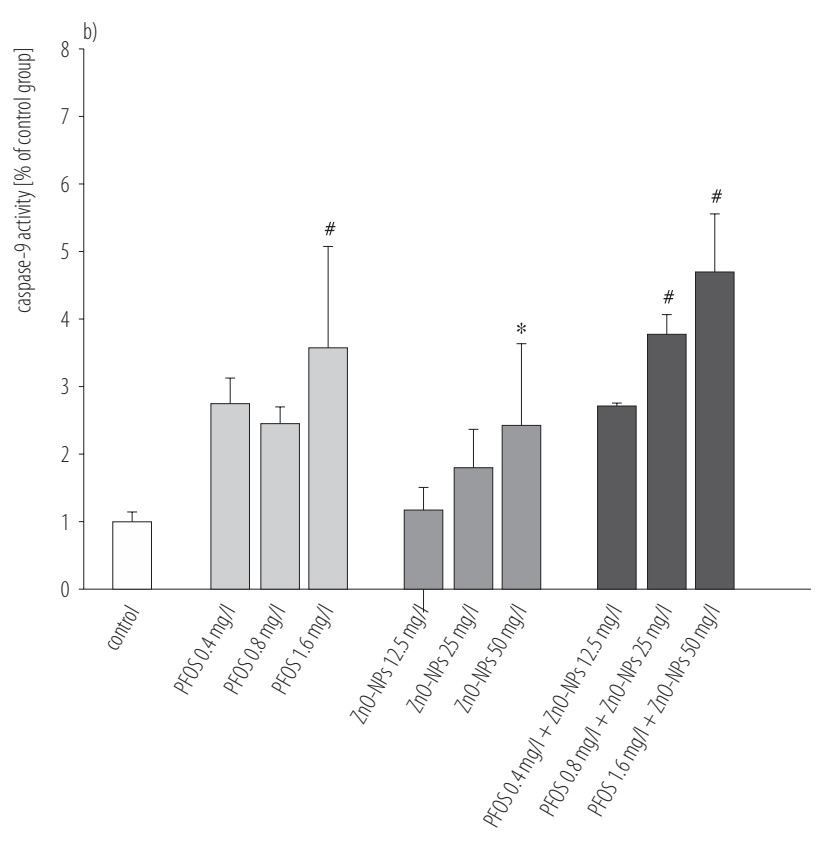

Study group exposure

Explanations as in Figure 1.

Fig. 4. Changes in the a) caspase-3 and b) caspase-9 activity in zebrafish embryos after exposure to perfluorooctane sulfonate (PFOS) and zinc oxide nanoparticles (ZnO-NPs) for $96 \mathrm{~h}$ post-fertilization

Moreover, the Caspase 9 activities in the ZnO-NPs cotreatment groups were significantly increased as compared with that in the $\mathrm{ZnO}-\mathrm{NPs}$ single-treatment groups.

\section{The expression level of gene related to apoptosis}

The expression of $p 53$ mRNA was up-regulated by 5.60 and 5.90 -fold in $1.6 \mathrm{mg} / \mathrm{l}$ of the PFOS single and joint exposure groups, respectively (Figure 5a). In addition, it was significantly up-regulated by 4.78 -fold in $50 \mathrm{mg} / \mathrm{l}$ of the $\mathrm{ZnO}-\mathrm{NPs}$ single exposure group compared to the control. The expression of $p 53$ mRNA in the $\mathrm{ZnO}$-NPs co-treatment groups was significantly increased as compared with that in the $\mathrm{ZnO}$-NPs single exposure groups. Transcription of Bax in $1.6 \mathrm{mg} / \mathrm{l}$ of the PFOS single-, $50 \mathrm{mg} / \mathrm{l}$ of the ZnO-NPs single-, 0.8 and $1.6 \mathrm{mg} / \mathrm{l}$ of the PFOS joint exposure groups were significantly up-regulated by 2.08, 1.43, 1.74 and 3.37fold as compared with that in the control (Figure 5b). In addition, the level of Bax expression in $1.6 \mathrm{mg} / \mathrm{l}$ of the PFOS joint exposure group was significantly increased to $1.6 \mathrm{mg} / \mathrm{l}$ of the PFOS single treatment and $50 \mathrm{mg} / \mathrm{l}$ of the $\mathrm{ZnO}$-NPs single treatment groups. The expression of the anti-apoptotic gene $\mathrm{Bcl}-2$ was significantly down-regulated by 0.31 -fold in $1.6 \mathrm{mg} / \mathrm{l}$ of the PFOS joint exposure group as compared with that in the control (Figure $5 \mathrm{c}$ ). Moreover, the expression of $\mathrm{Bcl}-2$ was significantly down-regulated by 0.76 and 0.70 -fold in $1.6 \mathrm{mg} / \mathrm{l}$ of the PFOS single- and $50 \mathrm{mg} / \mathrm{l}$ of the $\mathrm{ZnO}$-NPs single-treatment groups $(\mathrm{p}<0.05)$. The transcription of caspase-3 in the groups of $25 \mathrm{mg} / \mathrm{l}$ of the $\mathrm{ZnO}-\mathrm{NPs}$ single- and cotreatment were significantly up-regulated by 2.05 and 2.1-fold as compared to the control, respectively (Figure $5 \mathrm{~d})$. Moreover, the expression of caspase-3 gene in the groups of $50 \mathrm{mg} / \mathrm{l}$ of the $\mathrm{ZnO}-\mathrm{NPs}$ single- and co-treatment were significantly up-regulated by 2.46 and 2.96 fold in relation to the control. The levels of caspase-3 

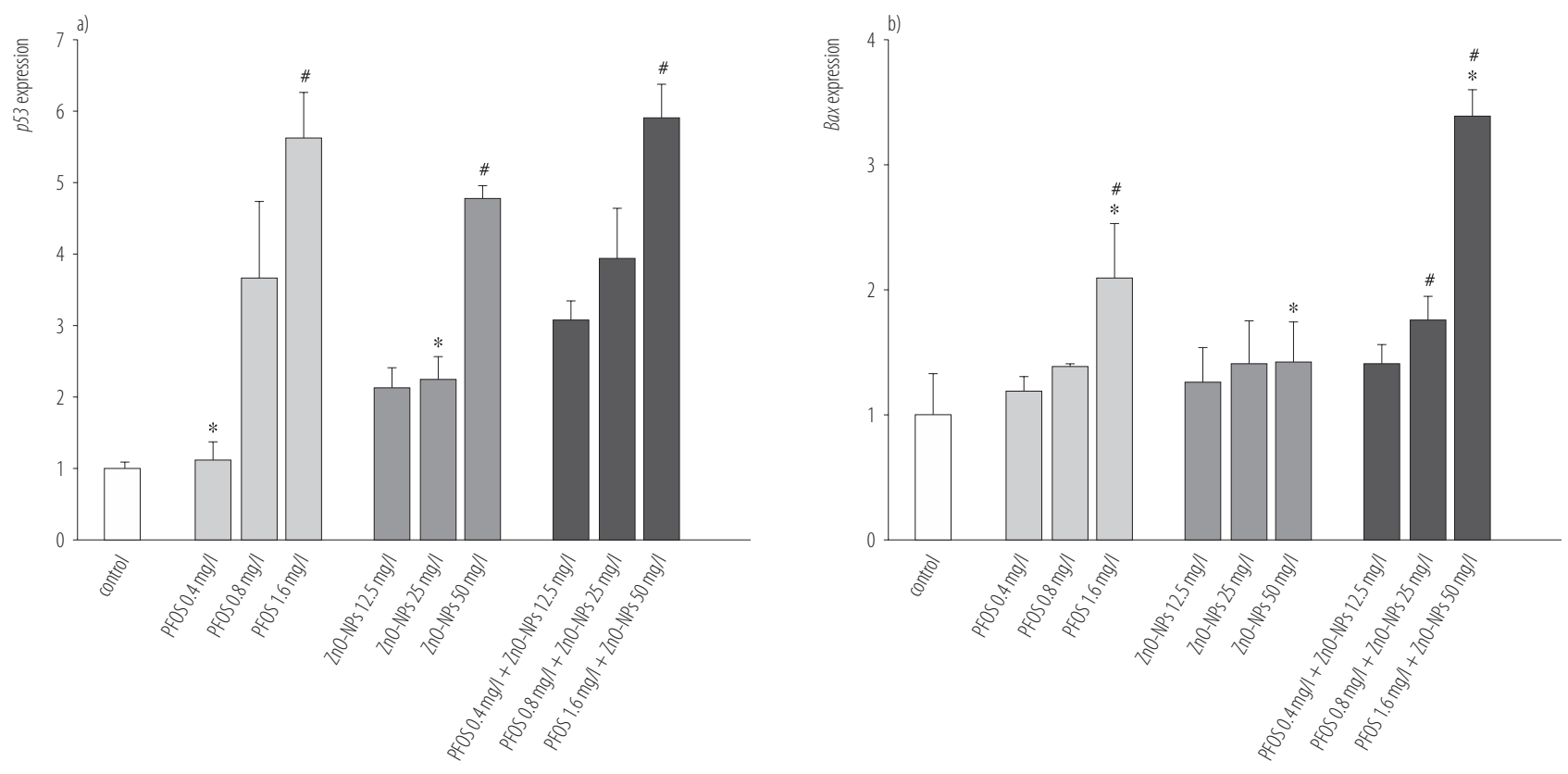

Study group exposure

Study group exposure
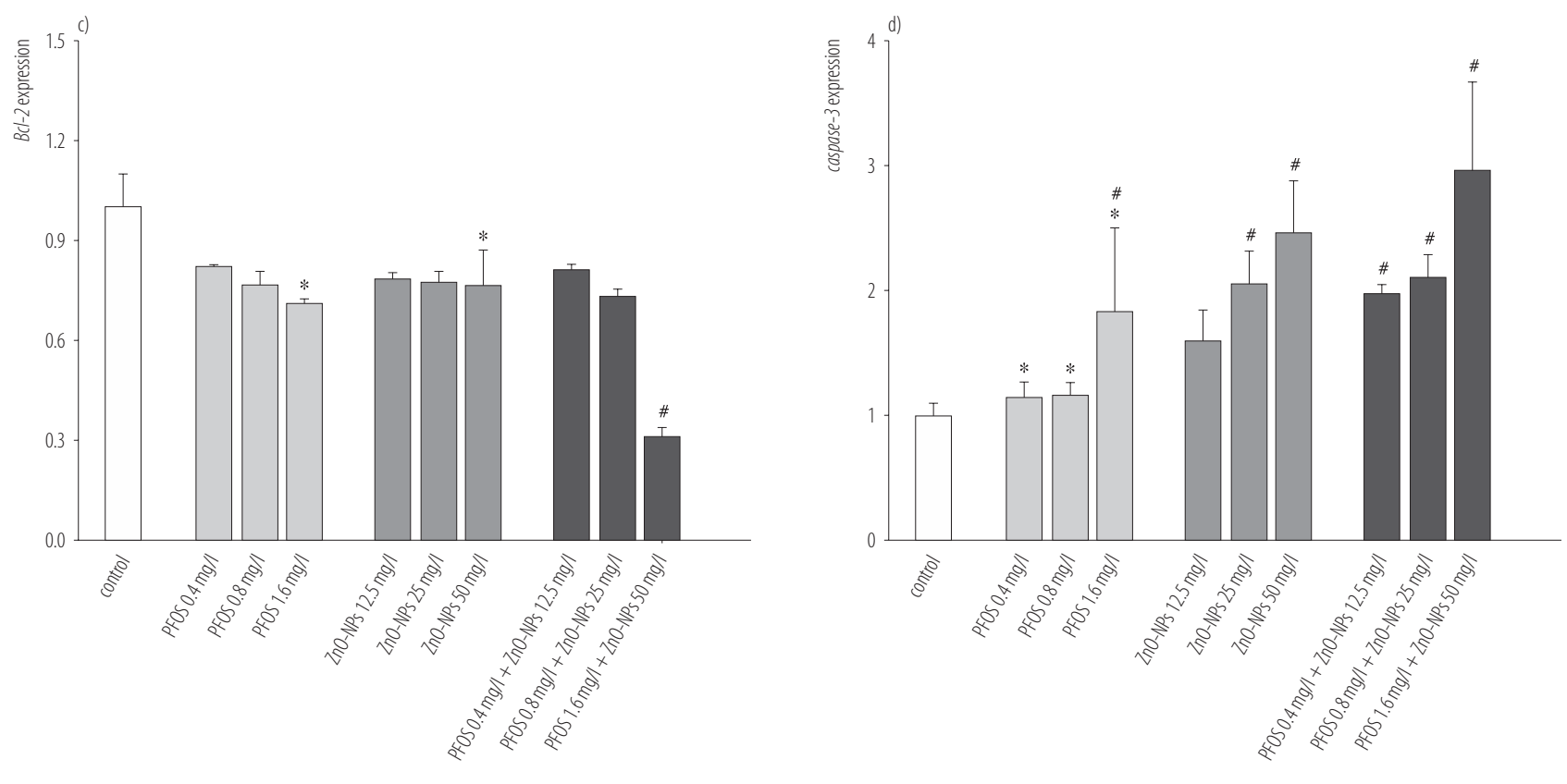

Study group exposure

Study group exposure

Fig. 5. a) p53, b) Bax, c) Bcl-2, d) caspase-3, and e) caspase-9 genes expression levels in zebrafish embryos after exposure to perfluorooctane sulfonate (PFOS) and zinc oxide nanoparticles (ZnO-NPs) at $96 \mathrm{~h}$ post-fertilization

expression in the PFOS co-treatment groups were significantly increased as compared with that in the PFOS single-treatment groups $(\mathrm{p}<0.05)$. The expression of the apoptosis gene caspase- 9 were significantly up-regulated by 3.66, 3.46, 3.56 and 4.96 -fold in $1.6 \mathrm{mg} / \mathrm{l}$ of the PFOS single, $50 \mathrm{mg} / \mathrm{l}$ of the $\mathrm{ZnO}$-NPs single, $25 \mathrm{mg} / \mathrm{l}$ of 


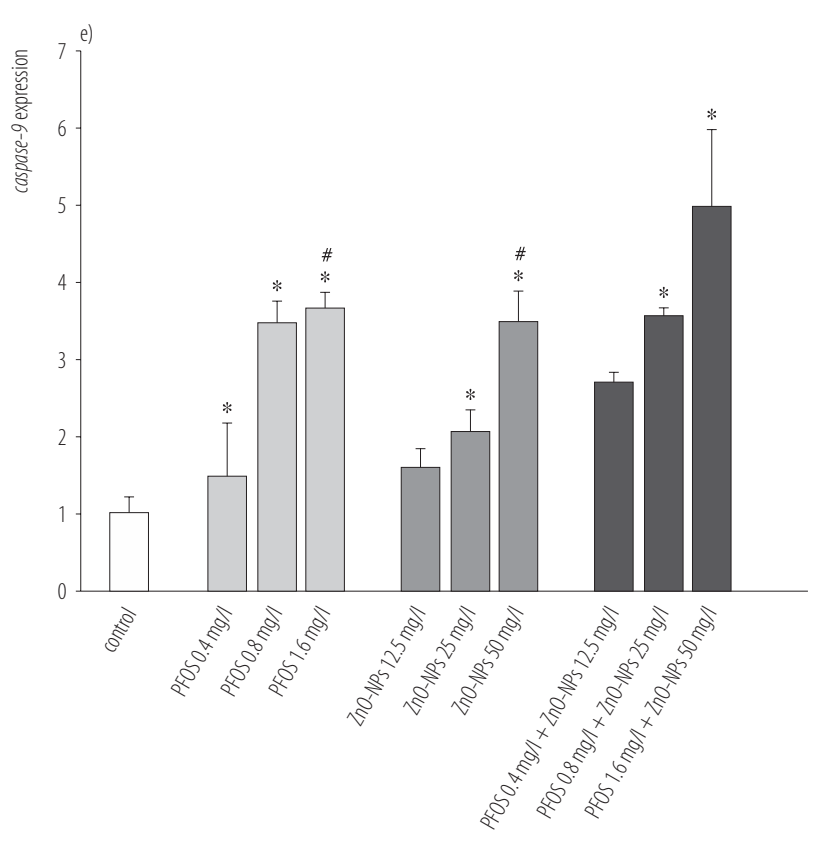

Study group exposure

Explanations as in Figure 1.

Fig. 5. a) p53, b) Bax, c) Bcl-2, d) caspase-3, and e) caspase- 9 genes expression levels in zebrafish embryos after exposure to perfluorooctane sulfonate (PFOS) and zinc oxide nanoparticles (ZnO-NPs) at $96 \mathrm{~h}$ post-fertilization - cont.

the $\mathrm{ZnO}$-NPs joint and $1.6 \mathrm{mg} / \mathrm{l}$ of the PFOS joint exposure groups as compared with that in the control, respectively (Figure $5 \mathrm{e}$ ). The expression of caspase- 9 mRNA in 25 and $50 \mathrm{mg} / \mathrm{l}$ of the $\mathrm{ZnO}$-NPs co-treatment groups was significantly increased compared to 25 and $50 \mathrm{mg} / \mathrm{l}$ of the $\mathrm{ZnO}$-NPs single exposure groups. There was also a significant increase in 0.4 and $1.6 \mathrm{mg} / \mathrm{l}$ of the PFOS joint exposure groups as compared with 0.4 and $1.6 \mathrm{mg} / \mathrm{l}$ of the PFOS single exposure groups ( $p<0.05)$.

\section{DISCUSSION}

This study has presented some evidence for the first time that the PFOS and ZnO-NPs co-exposure induce oxidative stress, apoptosis, as well as alterations in the expression of oxidant- and apoptosis-related genes in the early stages of zebrafish development. It has turned out that the synergistic effects play a more important role during the PFOS and ZnO-NPs joint exposure.

In our study, the PFOS and ZnO-NPs were found to generate intracellular ROS when analysed using cell permeable dye DCFH-DA. The concentration-dependent increase of the ROS in the organism exposure to the PFOS and $\mathrm{ZnO}-\mathrm{NPs}$ indicated that the embryos sustained more serious oxidative damage after joint exposure to the PFOS and ZnO-NPs. Qian et al. (2010) reported that the PFOS induced ROS production in human microvascular endothelial cells [41]. Zinc oxide nanoparticles exposure enhanced the ROS production in primary human $\mathrm{T}$ cells [42]. Malondialdehyde is a by-product of cellular lipid peroxidation. The results indicated that the PFOS and $\mathrm{ZnO}$-NPs single and co-treatment induced oxyradicals (Figure 1d). Glutathione peroxidase has a complementary role in hydrogen peroxide $\left(\mathrm{H}_{2} \mathrm{O}_{2}\right)$ detoxification and may reduce the tissue injury by removing $\mathrm{H}_{2} \mathrm{O}_{2}$. The glutathione peroxidase activity had significant differences between the PFOS and $\mathrm{ZnO}$-NPs single- and co-treatment groups (Figure 1c). The CAT activity was significantly decreased in $1.6 \mathrm{mg} / \mathrm{l}$ of the PFOS joint exposure group as compared to $1.6 \mathrm{mg} / \mathrm{l}$ of the PFOS single exposure group $(\mathrm{p}<0.05)$ (Figure $1 \mathrm{~b})$. The superoxide dismutase plays an important role in the anti-oxidant system and the CAT is a member of important antioxidases and both of them may eliminate the ROS in vivo. It was observed that the level of the SOD activity, Gpx activity and the MDA content were significantly increased in cotreatment groups as compared with those in single-treatment groups (Figure 1). Zinc oxide nanoparticles exposure induced developmental toxicity, oxidative stress and DNA damage in embryo-larval zebrafish [29]. Zinc oxide nanoparticles exposure induced oxidative stress in the gills, live and gut of zebrafish [43]. The perfluorooctane sulfonate exposure induced oxidative stress in the lung of rat off-spring [22]. The results showed the similar trend as the description of Kim and they found that 
pre-exposure to the PFOS affected antioxidant defence mechanisms and potentially increased of cadmium toxicity [44]. Alteration of these parameters indicated that oxidative stress-related processes were involved in the induced PFOS and $\mathrm{ZnO}-\mathrm{NPs}$ in vivo toxicity.

The expression levels of gene encoding for antioxidant proteins Sod1, Cat and Gpx1a were also analysed in the PFOS and ZnO-NPs treated zebrafish embryos. The expression level of Gpx1a and Cat gene were down-regulation after having been exposed to toxicants compared with that in the control (Figure 3a and 3b). In addition, the expression levels of Sod1 were not significantly affected by the PFOS and ZnO-NPs (Figure 3c). It had been previously demonstrated that expression levels of $\operatorname{Sod} 1$ were not affected after exposure to the ZnO-NPs and heavy metals ( $\mathrm{Zn}$ and $\mathrm{Cd}$ ) [45,46]. Zebrafish treated with silver nanoparticles also displayed down-regulated Cat and Gpx translation in liver [47], which provided further support to our results. In addition, it was demonstrated that the combination of the PFOS and ZnO-NPs had synergistic effects on the repression of antioxidant gene expression as well as the generation of oxidative stress in developmental zebrafish embryos.

To further investigate apoptosis caused by the PFOS and ZnO-NPs in zebrafish embryos, the caspase activity was measured using specific chromogenic substrates. From the Figure 4, it could be found that the PFOS and $\mathrm{ZnO}$-NPs induced the enhancement of the caspase- 3 and -9 activities in the zebrafish larvae. Wang et al. (2014) also reported that the $\mathrm{ZnO}$-NPs induced the caspase-3 activity in cultured primary astrocytes [28]. Chen et al. (2012) proved that the PFOS induced activity of the caspase- 3 and caspase- 9 upregulation in the lung of rat [22]. The Figure 5 showed that the PFOS and $\mathrm{ZnO}-\mathrm{NPs}$ induced apoptosis by up-regulation of $p 53$ and Bax gene expression in a dose-dependent manner. The $p 53$-related pro-apoptotic $B c l-2$ family genes were induced after the exposure to the PFOS and $\mathrm{ZnO}-\mathrm{NPs}$. The decrease was found in $B c l-2$ ratio along with increased caspase-3 and caspase-9 expression (Figure 5). Liu et al. (2007) also reported that the PFOS triggered the transactivation of Bax and activated caspase- 3 and caspase- 9 in zebrafish embryos [27]. Wang et al. (2014) reported that the ZnO-NPs induced Bax gene expression in cultured primary astrocytes [28]. Some researchers also found out that the $\mathrm{ZnO}-\mathrm{NPs}$ induced apoptotic cell death via $\mathrm{p} 53, \mathrm{Bax} / \mathrm{Bcl}-2$, and caspase pathways mediated by oxidative stress [20].

Nanoparticles interacted with other chemicals and induced joint toxicity effects on biology or environment. Wang et al. (2014) found out that some surfactants with different ion types could alter the properties of nanoparticles (particle size or surface charge) and present complex joint effects on nanoparticles toxicity [48]. Mixtures of different nanoparticles and surfactants exhibited antagonistic, synergistic, and additive effects. In the recent decades, some models have been developed to predict the joint effect of chemical mixtures on organisms and processes in the environment [30]. From the result of the ICP-MS, there was more soluble $\mathrm{Zn}^{2+}$ released from the $\mathrm{ZnO}$-NPs co-exposure suspensions than that from the ZnO-NPs single-exposure suspensions. Zinc oxide nanoparticles released $\mathrm{Zn}^{2+}[46]$ and the PFOS released anionic n-alkyl surfactants into solution [49]. The joint toxicity effect of the PFOS and $\mathrm{ZnO}-\mathrm{NPs}$ exposure could be explained in terms of interactions between the $\mathrm{Zn}^{2+}$ and the surfactants. Based on the structural characteristics of the PFOS and ZnO-NPs, the potential reasons and mechanism hypotheses are as follows: the surfactants may damage the membranes by perturbing the lipid bilayers [50,51]. Therefore, nanoparticles penetrated through cell membranes easier and caused more serious damage to zebrafish. A previous study proved that the mitochondrial membrane potential mediated the pathway involved in the ZnO-NPs induced apoptosis [52]. In this research, the joint effect of the PFOS and ZnO-NPs was presumed to be synergistic. The perfluorooctane sulfonate and some nanoparticles impaired the multi-xenobiotic resistance (MXR) mechanism, which resulted in the increased intracellular 
levels of other compounds, thereby potentiating their toxicity [53]. This study suggested that the PFOS increased the intracellular levels of the ZnO-NPs and induced more serious damage to organism. It suggests that the impact of other coexist compounds should be considered when the ecological risk assessments of the ZnO-NPs are made. Further work is required to find different mechanisms behind synergistic interactions, such as chemical uptake or chemical interactions outside the organism.

\section{CONCLUSIONS}

This is the first time to investigate the joint toxicity induced theFOS and $\mathrm{ZnO}-\mathrm{NPs}$ on zebrafish embryos. This study has demonstrated the occurrence of oxidative stress and apoptosis in the embryo-larval stages of zebrafish exposed to the PFOS and $\mathrm{ZnO}$-NPs. It has been proven that oxidative stress and apoptosis induced by the PFOS at different concentrations are enhanced in the presence of the $\mathrm{ZnO}$-NPs after $96 \mathrm{~h}$ exposure. The acute PFOS and $\mathrm{ZnO}-\mathrm{NPs}$ exposure induce oxidative stress and apoptosis through the excessive ROS, change the activities of the defence enzymes (SOD, CAT and Gpx), apoptosis enzymes (Caspase-3 and Caspase-9), and increase the MDA concentration in zebrafish larvae. In addition, It has also been revealed that the mRNA levels of genes, which encode in response to the oxidative damage (such as Cat and Gpx1a), induction genes in response to apoptosis (such as p53, Bax, Bcl-2, caspase-3 and caspase-9), are also significantly altered in larvae zebrafish after the PFOS and $\mathrm{ZnO}$ NPs joint exposure. In conclusion, the combination of the PFOS and ZnO-NPs has synergistic effects on induction of oxidative stress and apoptosis. The observed synergism suggests that the inclusion of mixture considerations in the risk assessment of the PFOS and ZnO-NPs is needed.

\section{ACKNOWLEDGMENTS}

The authors would like to acknowledge the support from the State Key Laboratory of Urban Water Resource and En- vironment (Harbin Institute of Technology) (No. 2013DX09), and the support from the Center of Urban Governance Studies (the International Urbanology Studies Center City of Hangzhou) (The theory research of the TOD mode oriented urban agglomeration development) (No. 71540005).

\section{REFERENCES}

1. Lanone S, Boczkowski J. Biomedical applications and potential health risks of nanomaterials: Molecular mechanisms. Curr Mol Med. 2006;6(6):651-63, https://doi.org/ 10.2174/156652406778195026.

2. Gottschalk F, Sonderer T, Scholz RW, Nowack B. Modeled environmental concentrations of engineered nanomaterials (TiO2, $\mathrm{ZnO}, \mathrm{Ag}, \mathrm{CNT}$, Fullerenes) for different regions. Environ Sci Technol. 2009;43(24):9216-22, https://doi.org/10.1021/ es 9015553.

3. Franklin NM, Rogers NJ, Apte SC, Batley GE, Gadd GE, Casey PS. Comparative toxicity of nanoparticulate $\mathrm{ZnO}$, bulk $\mathrm{ZnO}$, and $\mathrm{ZnCl} 2$ to a freshwater microalga (Pseudokirchneriella subcapitata): The importance of particle solubility. Environ Sci Technol. 2007;41(24):8484-90, https://doi.org/10.1021/ es071445r.

4. Gojova A, Guo B, Kota RS, Rutledge JC, Kennedy IM, Barakat AI. Induction of inflammation in vascular endothelial cells by metal oxide nanoparticles: Effect of particle composition. Environ Health Persp. 2007;115(3):403-9, https://doi. org/10.1289/ehp.8497.

5. Lin WS, Xu Y, Huang CC, Ma YF, Shannon KB, Chen DR, et al. Toxicity of nano- and micro-sized $\mathrm{ZnO}$ particles in human lung epithelial cells. J Nanopart Res. 2009;11(1):25-39, https://doi.org/10.1007/s11051-008-9419-7.

6. Sharma V, Anderson D, Dhawan A. Zinc oxide nanoparticles induce oxidative DNA damage and ROS-triggered mitochondria mediated apoptosis in human liver cells (HepG2). Apoptosis. 2012;17(8):852-70, https://doi.org/10.1007/s10 495-012-0705-6.

7. Thibodeaux JR, Hanson RG, Rogers JM, Grey BE, Barbee BD, Richards JH, et al. Exposure to perfluorooctane 
sulfonate during pregnancy in rat and mouse. I: Maternal and prenatal evaluations. Toxicol Sci. 2003;74(2):369-81, https://doi.org/10.1093/toxsci/kfg121.

8. Lau C, Thibodeaux JR, Hanson RG, Rogers JM, Grey BE, Stanton ME, et al. Exposure to perfluorooctane sulfonate during pregnancy in rat and mouse. II: Postnatal evaluation. Toxicol Sci. 2003;74(2):382-92, https://doi.org/10.1093/toxsci//fg122.

9. Wan YJ, Li YY, Xia W, Chen J, Lv ZQ, Zeng HC, et al. Alterations in tumor biomarker GSTP gene methylation patterns induced by prenatal exposure to PFOS. Toxicology. 2010;274(1-3):57-64, https://doi.org/10.1016/j.tox. 2010.05.006.

10. So MK, Taniyasu S, Yamashita N, Giesy JP, Zheng J, Fang Z, et al. Perfluorinated compounds in coastal waters of Hong Kong, South China, and Korea. Environ Sci Technol. 2004;38(15):4056-63, https://doi.org/10.1021/es049441z.

11. Hansen KJ, Johnson HO, Eldridge JS, Butenhoff JL, Dick LA. Quantitative characterization of trace levels of PFOS and PFOA in the Tennessee River. Environ Sci Technol. 2002;36(8):1681-5, https://doi.org/10.1021/es010780r.

12. Skutlarek D, Exner M, Farber H. Perfluorinated surfactants in surface and drinking water. Environ Sci Pollut R. 2006;13(5):299-307, http://doi.org/10.1065/espr 2006.07.326.

13. Jin YH, Liu W, Sato I, Nakayama SF, Sasaki K, Saito N, et al. PFOS and PFOA in environmental and tap water in China. Chemosphere. 2009;77(5):605-11, https://doi.org/10.1016/ j.chemosphere.2009.08.058.

14. Du YB, Shi XJ, Liu CS, Yu K, Zhou BS. Chronic effects of water-borne PFOS exposure on growth, survival and hepatotoxicity in zebrafish: A partial life-cycle test. Chemosphere. 2009;74(5):723-9, https://doi.org/10.1016/j.chemosphere.2008.09.075.

15. Kim WK, Lee SK, Jung J. Integrated assessment of biomarker responses in common carp (Cyprinus carpio) exposed to perfluorinated organic compounds. J Hazard Mater. 2010;180(1-3): 395-400, https://doi.org/10.1016/j.jhazmat.2010.04.044.
16. Keiter S, Baumann L, Farber H, Holbech H, Skutlarek D, Engwall M, et al. Long-term effects of a binary mixture of perfluorooctane sulfonate (PFOS) and bisphenol A (BPA) in zebrafish (Danio rerio). Aquat Toxicol. 2012;118:116-29, https://doi.org/10.1016/j.aquatox.2012.04.003.

17. Nel A, Xia T, Madler L, Li N. Toxic potential of materials at the nanolevel. Science. 2006;311(5761):622-7, https://doi. org/10.1126/science.1114397.

18. Limon-Pacheco J, Gonsebatt ME. The role of antioxidants and antioxidant-related enzymes in protective responses to environmentally induced oxidative stress. Mutat Res Genet Toxicol Environ Mutagen. 2009;674(1-2):137-47, http://doi. org/10.1016/j.mrgentox.2008.09.015.

19. Valavanidis A, Vlahogianni T, Dassenakis M, Scoullos M. Molecular biomarkers of oxidative stress in aquatic organisms in relation to toxic environmental pollutants. Ecotoxicol Environ Saf. 2006;64(2):178-89, http://doi.org/10.1016/ j.ecoenv.2005.03.013.

20. Ahamed M, Akhtar MJ, Raja M, Ahmad I, Siddiqui MKJ, AlSalhi MS, et al. $\mathrm{ZnO}$ nanorod-induced apoptosis in human alveolar adenocarcinoma cells via p53, survivin and bax/bcl-2 pathways: Role of oxidative stress. Nanomedicine. 2011;7(6):904-13, http://doi.org/10.1016/j.nano. 2011.04.011.

21. Zhu XS, Wang JX, Zhang XZ, Chang Y, Chen YS. The impact of $\mathrm{ZnO}$ nanoparticle aggregates on the embryonic development of zebrafish (Danio rerio). Nanotechnology. 2009;20(19), https://doi.org/10.1088/0957-4484/20/19/195103.

22. Chen T, Zhang L, Yue JQ, Lv ZQ, Xia W, Wan YJ, et al. Prenatal PFOS exposure induces oxidative stress and apoptosis in the lung of rat off-spring. Reprod Toxicol. 2012;33(4): 538-45, https://doi.org/10.1016/j.reprotox.2011.03.003.

23. Fan TJ, Han LH, Cong RS, Liang J. Caspase family proteases and apoptosis. Acta Biochim Biophys Sin. 2005;37(11):71927, https://doi.org/10.1111/j.1745-7270.2005.00108.x.

24. Langheinrich U, Hennen E, Stott G, Vacun G. Zebrafish as a model organism for the identification and characterization of drugs and genes affecting p53 signaling. Curr 
Biol. 2002;12(23):2023-8, https://doi.org/10.1016/S0960-98 22(02)01319-2.

25. Sheikh MS, Fornace AJ. Role of p53 family members in apoptosis. J Cell Physiol. 2000;182(2):171-81, http://doi. org/10.1002/(Sici)1097-4652(200002)182:2<171::AidJcp5>3.0.Co;2-3.

26. Gross A, McDonnell JM, Korsmeyer SJ. BCL-2 family members and the mitochondria in apoptosis. Genes Dev. 1999;13(15):1899-911, http://doi.org/10.1101/gad.13. 15.1899.

27. Liu CS, Yu K, Shi XJ, Wang JX, Lam PKS, Wu RSS, et al. Induction of oxidative stress and apoptosis by PFOS and PFOA in primary cultured hepatocytes of freshwater tilapia (Oreochromis niloticus). Aquat Toxicol. 2007;82(2):135-43, https://doi.org/10.1016/j.aquatox.2007.02.006.

28. Wang J, Deng X, Zhang F, Chen D, Ding W. ZnO nanoparticle-induced oxidative stress triggers apoptosis by activating JNK signaling pathway in cultured primary astrocytes. Nanoscale Res Lett. 2014;9(1):117, https:/doi. org/10.1186/1556-276X-9-117.

29. Zhao XS, Wang ST, Wu Y, You H, Lv LN. Acute ZnO nanoparticles exposure induces developmental toxicity, oxidative stress and DNA damage in embryo-larval zebrafish. Aquat Toxicol. 2013;136:49-59, https://doi.org/10.1016/ j.aquatox.2013.03.019.

30. George TK, Liber K, Solomon KR, Sibley PK. Assessment of the probabilistic ecological risk assessment-toxic equivalent combination approach for evaluating pesticide mixture toxicity to zooplankton in outdoor microcosms. Arch Environ Contam Toxicol. 2003;45(4):453-61, http://doi.org/10.1007/s00244-003-2123-9.

31. Altenburger R, Scholz S, Schmitt-Jansen M, Busch W, Eschert BI. Mixture toxicity revisited from a toxicogenomic perspective. Environ Sci Technol. 2012;46(5):2508-22, https://doi.org/10.1021/es2038036.

32. Sarigiannis DA, Hansen U. Considering the cumulative risk of mixtures of chemicals - A challenge for policy makers. Environ Health. 2012;11(Suppl 1):S18, http://doi. org/10.1186/1476-069x-11-S1-S18.
33. Shi XJ, Liu CS, Wu GQ, Zhou BS. Waterborne exposure to PFOS causes disruption of the hypothalamuspituitary-thyroid axis in zebrafish larvae. Chemosphere. 2009;77(7):1010-8, https://doi.org/10.1016/j.chemosphere. 2009.07.074.

34. Lema SC, Schultz IR, Scholz NL, Incardona JP, Swanson P. Neural defects and cardiac arrhythmia in fish larvae following embryonic exposure to 2,2',4,4'-tetrabromodiphenyl ether (PBDE 47). Aquat Toxicol. 2007;82(4):296-307, https://doi.org/10.1016/j.aquatox.2007.03.002.

35. Magwere T, Naik YS, Hasler JA. Effects of chloroquine treatment on antioxidant enzymes in rat liver and kidney. Free Radic Biol Med. 1997;22(1-2):321-7, http://doi.org/10.1016/ S0891-5849(96)00285-7.

36. Clairborne A. Catalase activity. In: Greewald AR, editor. Handbook of methods for oxygen radical research. Florida: CRC Press; 1995. p. 237-42.

37. Esterbauer H, Cheeseman KH. Determination of aldehydic lipid peroxidation products: Malonaldehyde and 4-hydroxynonenal. Methods Enzymol. 1990;186:407-21, https:// doi.org/10.1016/0076-6879(90)86134-H.

38. Paglia DE. Erythroenzymopathies - 1960s in retrospect A citation classic commentary on studies on the quantitative and qualitative characterization of erythrocyte glutathione peroxidase by Paglia, D.E. and Valentine, W.N. Curr Contents Clin Med. 1989;8(16).

39. Bradford MM. A rapid and sensitive method for the quantitation of microgram quantities of protein utilizing the principle of protein-dye binding. Anal Biochem. 1976;72:248-54, https://doi.org/10.1016/0003-2697(76)90527-3.

40. Livak KJ, Schmittgen TD. Analysis of relative gene expression data using real-time quantitative PCR and the $2^{-\Delta \Delta C T}$ method. Methods. 2001;25(4):402-8, https://doi.org/10.1006/ meth.2001.1262.

41. Qian Y, Ducatman A, Ward R, Leonard S, Bukowski V, Guo NL, et al. Perfluorooctane sulfonate (PFOS) induces reactive oxygen species (ROS) production in human microvascular endothelial cells: Role in endothelial permeability. 
J Toxicol Environ Health A. 2010;73(12):819-36, https://doi. org/10.1080/15287391003689317.

42. Hanley C, Layne J, Punnoose A, Reddy KM, Coombs I, Coombs A, et al. Preferential killing of cancer cells and activated human $\mathrm{T}$ cells using $\mathrm{ZnO}$ nanoparticles. Nanotechnology. 2008;19(29):295103, https://doi.org/10.1088/0957-4484/ 19/29/295103.

43. Xiong DW, Fang T, Yu LP, Sima XF, Zhu WT. Effects of nano-scale $\mathrm{TiO}_{2}, \mathrm{ZnO}$ and their bulk counterparts on zebrafish: Acute toxicity, oxidative stress and oxidative damage. Sci Total Environ. 2011;409(8):1444-52, https://doi.org/10.1016/ j.scitotenv.2011.01.015.

44. Kim S, Ji K, Lee S, Lee J, Kim J, Kim S, et al. Perfluorooctane sulfonic acid exposure increases cadmium toxicity in early life stage of zebrafish, Danio rerio. Environ Toxicol Chem. 2011;30(4):870-7, https://doi.org/10.1002/etc.443.

45. Hansen BH, Romma S, Garmo OA, Pedersen SA, Olsvik PA, Andersen RA. Induction and activity of oxidative stress-related proteins during waterborne $\mathrm{Cd} / \mathrm{Zn}$-exposure in brown trout (Salmo trutta). Chemosphere. 2007;67(11):2241-9, https://doi.org/10.1016/j.chemosphere.2006.12.048.

46. Wong SWY, Leung PTY, Djurisic AB, Leung KMY. Toxicities of nano zinc oxide to 5 marine organisms: Influences of aggregate size and ion solubility. Anal Bioanal Chem. 2010;396(2):609-18, https://doi.org/10.1007/s00216-009-3249-z.

47. Choi JE, Kim S, Ahn JH, Youn P, Kang JS, Park K, et al. Induction of oxidative stress and apoptosis by silver nanoparti- cles in the liver of adult zebrafish. Aquat Toxicol. 2010;100(2): 151-9, https://doi.org/10.1016/j.aquatox.2009.12.012.

48. Wang DL, Lin ZF, Yao ZF, Yu HX. Surfactants present complex joint effects on the toxicities of metal oxide nanoparticles. Chemosphere. 2014;108:70-5, https://doi.org/10.1016/ j.chemosphere.2014.03.010.

49. Harada K, Xu F, Ono K, Iijima T, Koizumi A. Effects of PFOS and PFOA on L-type $\mathrm{Ca}^{2+}$ currents in guinea-pig ventricular myocytes. Biochem Biophys Res Commun. 2005; 329(2):487-94, http://doi.org/10.1016/j.bbrc.2005.01.163.

50. Ahn CY, Joung SH, Jeon JW, Kim HS, Yoon BD, Oh HM. Selective control of cyanobacteria by surfactin-containing culture broth of Bacillus subtilis C1. Biotechnol Lett. 2003;25(14): 1137-42, https://doi.org/10.1023/A:1024508927361.

51. Grau A, Fernandez JCG, Peypoux F, Ortiz A. A study on the interactions of surfactin with phospholipid vesicles. BBA Biomembranes. 1999;1418(2):307-19, http://doi.org/10.1016/ S0005-2736(99)00039-5.

52. Desagher S, Martinou JC. Mitochondria as the central control point of apoptosis. Trends Cell Biol. 2000;10(9):369-77, https://doi.org/10.1016/S0962-8924(00)01803-1.

53. Anselmo HMR, van den Berg JHJ, Rietjens IMCM, Murk AJ. Inhibition of cellular efflux pumps involved in multi xenobiotic resistance (MXR) in echinoid larvae as a possible mode of action for increased ecotoxicological risk of mixtures. Ecotoxicology. 2012;21(8):2276-87, https://doi. $\operatorname{org} / 10.1007 / \mathrm{s} 10646-012-0984-2$.

This work is available in Open Access model and licensed under a Creative Commons Attribution-NonCommercial 3.0 Poland License - http://creativecommons.org/ licenses/by-nc/3.0/pl/deed.en. 